\title{
Clash of Civilizations? \\ An Evolution-Theoretic and Empirical Investigation of Huntington's Theses
}

\author{
GERHARD SCHURZ, DUESSELDORF
}

\section{Huntington's Theses}

With his article "Clash of Civilizations" (Foreign Affairs 1993) and his book of (1996) Samuel P. Huntington, Professor for Politics at Harvard, created world-wide attention, which was amplified through the tragic event of September $11^{\text {th }}$, whose consequences culminated into a still lasting word-wide debate. Huntington's position can be summarized in the following three theses.

Huntington's thesis no. 1: This thesis is historical. It says that after the era of colonialism and the consecutive era of cold war, which ended with the breakdown of communism, the world has entered a new era, in which the artificial political division of the world is replaced by the more natural division of the world in historically old worldwide 'civilizations' which through the process of global networking come more and more in mutual conflict:

1st World War Collapse of Communism Since 1990ies:

\begin{tabular}{llll} 
& $\forall$ & \\
\hline Era of colonialism & Era of cold war & Era of clash of civilizations \\
Western hegemony & Artificial division of & Natural division of world \\
& world into two blocks & into worldwide cultures
\end{tabular}

Huntington's thesis no. 2: According to Huntington, our world is naturally divided into civilizations or world-cultures. These are historically enduring constitutions of human societies, primarily characterized by religion, and secondarily by common history and by geographical region.

Huntington distinguishes the following eight world-cultures. Four of them are historically very old and more-or-less independent world-cultures, while the other four are partly derived (the last one is a 'family'):

Four large and historically old cultural blocks:

1) The Sinic or Chinese world-culture which begins 1500 B.C. and is 
mainly Confucianistic.

2) The Hinduistic world-culture on the Indian subcontinent which begins around 1500 B. C.

3) The Islamic world-culture which begins 700 A.C. and has spread from the Arabic peninsula to central Asia, parts of the Indian subcontinent and of Indonesia.

4) The western world-culture which mainly determined by Christian religion. It begins around 700 A.C. and has spread from Western Europe to North America and Latin America.

In part historically derived are:

5) The orthodox-Christian world-culture in the ex-communistic countries of Eastern Europe and North Asia.

6) The Latin-American world-culture, which is closely related to the western world-culture.

7) The Japanese world-culture, which has developed from the Chinese world-culture beginning in 100-400 A.C.

8) The African family of cultures - because of the diversity of tribal identities and it is questionable, says Huntington, whether one can speak here of one world-culture.

Huntington's critics have soon noticed several general problems which are involved in Huntington's classification of world-cultures, such as the following:

- Can the major characteristic of contemporary world-cultures be really defined by religious attributes?

- Are these world-cultures really historically enduring characteristics haven't these world-cultures drastically changed through historical time?

- Does an Orthodox-Christian world-culture really exist - aren't these countries similar because of their ex-communistic history?

- Is the Western world-culture really homogeneous?

Apart from these general problems, which will be analyzed in the next sections, several special problems have been popped up through the Huntington-debate, for example: Why is Buddhism missing (the fifth 'worldreligion; cf. Huntington 1996, 61)? Why is the starting point of western culture set at 700 A.C. (and not, for example, 600 B.C. with the ancient Greek empire)? Given that Japan is included, why not Korea? What stands behind the 'family' of African cultures?, etc. However that may be, it does not tangle Huntington's third, major and most provocative thesis, which is 
the following:

Huntington's thesis no. 3: The western ideal of universal modernization - western democracy \& free-market economy as the direction in which all countries will develop if one gives them independence and imports western know-how (the world-wide 'Marshall plan') - is false.

Rather, our world divides itself naturally along the above world-cultures. They are more-or-less in mutual conflict with each other, and in part even incommensurable. They should better not be mixed.

Western societies, and in particular the USA, should retreat as a leading model from the international level. At the same time they should protect their culture against too many immigrants from incommensurable cultures (Huntington 1996, 524).

Huntington supports his theses by the following evidences:

- Non-western countries have taken over western technology, science and economy. But at the same time, they have kept or even strengthened their own cultural traditions. This is especially true for the east-Indian countries which had an enormous economic boom - Hong Kong, Taiwan, Southern Korea, Singapore, China, Malaysia, Thailand, and Indonesia (Huntington 1996, 129, 156-9, 167).

- Scientists of religion speak about a world-wide come-back of religious orientations with increasing fundamentalist tendencies - especially in the Islamic countries, in India, South America, in the ex-communist countries, and even in the USA (cf. Huntington 1996, 135, 144, 149; Kienzler 1996, 28ff; Riesebrodt 2000, 122). According to Huntington, the reason for this come-back is an intrinsic crisis of modernity: as a reaction to post-modern orientation-less and moral de-stabilization people turn back to religion-based absolute value-systems (Huntington 1996, 146).

\section{Huntington's 'World-Cultures' from an Evolutionary Viewpoint}

I think that Huntington's view of world-cultures as historically enduring characteristics is wrong. The following simple observation makes this plain:

Anti-thesis to Huntington: the western-Christian world-cultures in Europe's premodern time, from 800 to 1800 B.C., are much more similar to the contemporary nonWestern societies (e.g. the Islamic countries) as to the modern Western societies. 
My anti-thesis is can be supported by many facts, and I mention only a few of them:

- Contemporary Confucian values fit quite well with the conservative values of the European citizens in 19th century (cf. Müller 1998).

- There are many parallels between contemporary Islamic countries and European countries in the times when their were rule by Christian religion: Dschihad had its parallel in Christian crusades, submission of females under males was also central to Christian moral, and the postmodern liberties, e.g. concerning permissive clothing fashions, would have shocked my grand mother in a similarly drastic way as Islamic fundamentalists. In general, Jewish, Christian and Islamic religion are very similar to each other and have presumably the same historical roots.

Therefore I arrive at the following evolutionary diagnosis:

Evolutionary diagnosis: Huntington's so-called world-cultures seem to be momentary developmental stages of certain cultural evolutionary processes. The reason for the contemporary clashes between world-cultures lies not so much in their intrinsic differences, but is the effect of the huge temporal displacement ('time shift') between their development stages - concerning economic and industrial development, and concerning secularization democratization.

In fact, the secularization of Christianity was a slow and difficult historical process, and given that Mohammed came six centuries later than Christ, it is prima facie not implausible that the secularization of Islam will simply need some more centuries of time.

But even if my evolutionary diagnosis is true, there is an important successor question:

Does the long-term development of societies go into more-or-less the same direction, into the direction of modernization?

Or do different cultures develop into different directions? - in which case Huntington's theses would still have their point!

These are the central question of Inglehart's empirical investigation, to which I turn in the next section. 


\section{Ronald Inglehart's World Value Survey: Empirical Investigation of World-Cultures}

Most of the contemporary discussions about Huntington and his theses about the clash between world-cultures are full of pro's and con's, but they are in lack of systematic empirical evidence (cf. Metzinger 2000 as a typical example). The more important are the empirical studies of the Word Value Survey (WVS) project which has been founded by Ronald Inglehart at the University of Michigan, and which can be accessed at the WVS homepage http://wvs.isr.umich.edu/index.html. In this project, social scientists have developed and successively improved detailed questionnaires, by which people in more than 65 countries are asked questions concerning

- their attitudes towards religion, authority, labor, family, political organization, personal self realization, gender roles, homosexuality, liberty, etc.

- their lifestyle: married or single, how much time they spend for work, family, clubs, etc.

Each answer to a question corresponds to one empirical variable (which is standardized on an interval scale: mean $=0$, standard deviation $=1$ ). In order to interpret the more than 250 variables (answers), Inglehart has performed a factor analysis. In several independent WVS-studies or 'waves' (1990, 1995, 2000, 2005), two stable (statistically independent) factors have been obtained which explain more than $50 \%$ of the total variance of the empirical variables. The factor analysis has been performed with nations as empirical units, i.e., with the mean values for each country. The two obtained factors or 'theoretical parameters' correspond to latent causes of highly intercorrelated empirical variables; and they are best understood by recognizing the types of answers with which they have high correlations (or 'loadings'):

Factor 1: tradition-religious versus secular-rational orientation:

Correlates with: religious vs. rational-secular value-orientation, importance of family bonds vs. individual freedom, national pride high vs. low, respect vis-à-vis state authority high vs. low, birth rate high vs. low, estimation of labor high vs. low.

The transition on the 1st factor axis from traditional-religious to rationalsecular values corresponds to the social transition from agraic to industrial civilizations - the so-called process of modernization. 
Factor 2: survival values versus self-expression values:

Correlates with: low vs. high economic standards of life, importance of existential security \& wok vs. pleasure \& life-quality, low vs. high appreciation of gender equality, rejection vs. acceptance of homosexuality, intolerance vs. tolerance towards foreign immigrants, low vs. high interpersonal trust, acceptance vs. non-acceptance of authoritarian regimes, devaluation vs. appreciation of democracy.

The transition from survival to self-expression values corresponds socially to the transition from industrial to post-industrial societies with a high prosperity level and a dense social service infrastructure - the so-called process of post-modernization.

In his earlier books (cf. 1998), Inglehart defended a version of modernization theory in which more-or-less all nations follow in their development the same major modernization trends:

agrarian $\longrightarrow$ industrial

modernization (factor 1) post-modernization (factor 2)

Because of the WVS-data, Inglehart later weakens his view and recognizes a large amount of culture-specific path-dependence in this development (cf. Inglehart 2004, 141). In fact, it seems to me that Inglehart's modernization theory is even less supported by the WVS-data as Inglehart seems to think. In part, the WVS-data support a modified Huntington-type thesis about divergent developments of world-cultures, although Huntington's own classification of world-cultures is falsified by the data in many respects.

Fig. 1 shows the most recent cultural world map of nations based on the WVS-data of 2000 and 2005 (they include more nations than 1995). Some typical attitudes which correspond to different positions on this cultural world-map are shown in fig. 2. A closer inspection of figure 1 leads to the following remarkable observations:

$\Rightarrow$ The nations are not correlated along one path - for example along the diagonal path, which would be predicted by a simple 'monotonic' modernization theory. Rather, they are statistically independent along the two factors. Already this fact proves that there is a large amount of cultural divergence which cannot only be explained by temporal displacement in development.

$\Rightarrow$ The map exhibits cultural world-regions and, insofar, is in support of Huntington. But only some of Inglehart's cultural world-regions are in conformity with Huntington. 
$\Rightarrow$ The Islamic countries are, as to be expected, in the lower-left corner, representing high traditional-religious and self-survival values, or low modernization development. Only the African countries are even more traditional.

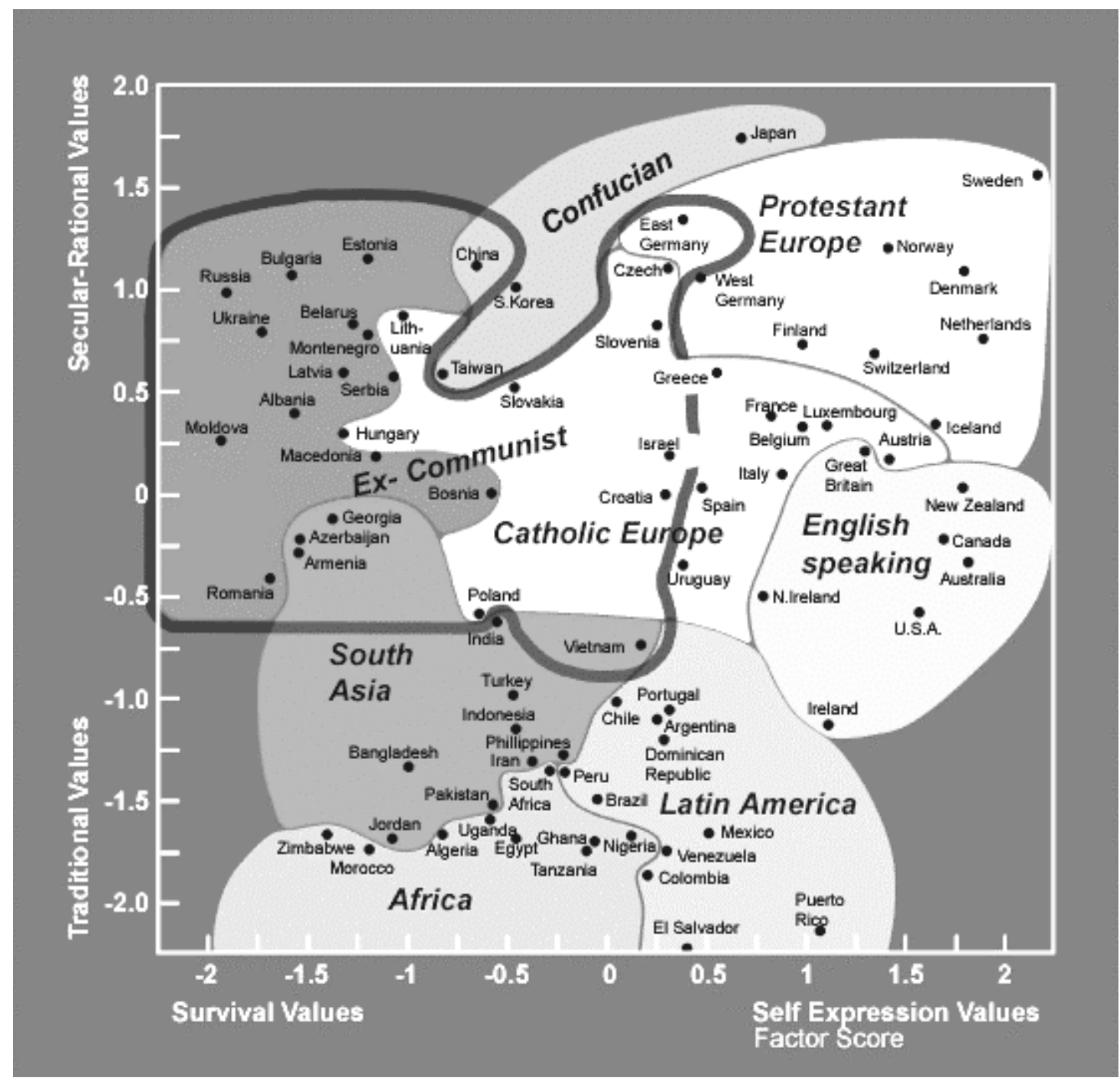

Fig. 1 The cultural world-map. Most recent data from 2000 and 2005. (Source: http://wvs.isr.umich.edu/index.html)

$\Rightarrow$ The ex-communist countries have a striking position, highly rationalsecularized though not post-modernized. This supports the view that their ex-communist history rather than orthodox Christianity is the major cause of their similarity. But also the east-Asian countries fit in this area: they also have an ex-communist history; but in addition their Confucian tradition was secular since early historical times. In this respect the east-Asian countries differ strongly from other world-cultures. 
$\Rightarrow$ The so-called western Christian world-culture is very divergent - so divergent that it is doubtful to subsume it under one world-culture. At least, the religious characterization as 'Christian' seems to have little content. The cultural distance between extremely post-modernized countries in protestantic Europe (say Sweden) to rather medium-positioned countries in catholic Europe (say Italy) is bigger than the distance of the latter countries and, e.g., Islamic countries.

$\Rightarrow$ Western and eastern European countries taken together make up two thirds of the entire cultural map - which means that the task to establish a cultural European identity is almost as difficult as to establish a cultural world identity.

$\Rightarrow$ The English speaking countries have a characteristically different position than the continental-European countries: the combine highly traditional-religious orientations with high level of post-modernization - which is, by the way, the opposite combination than that of the ex-communist countries.

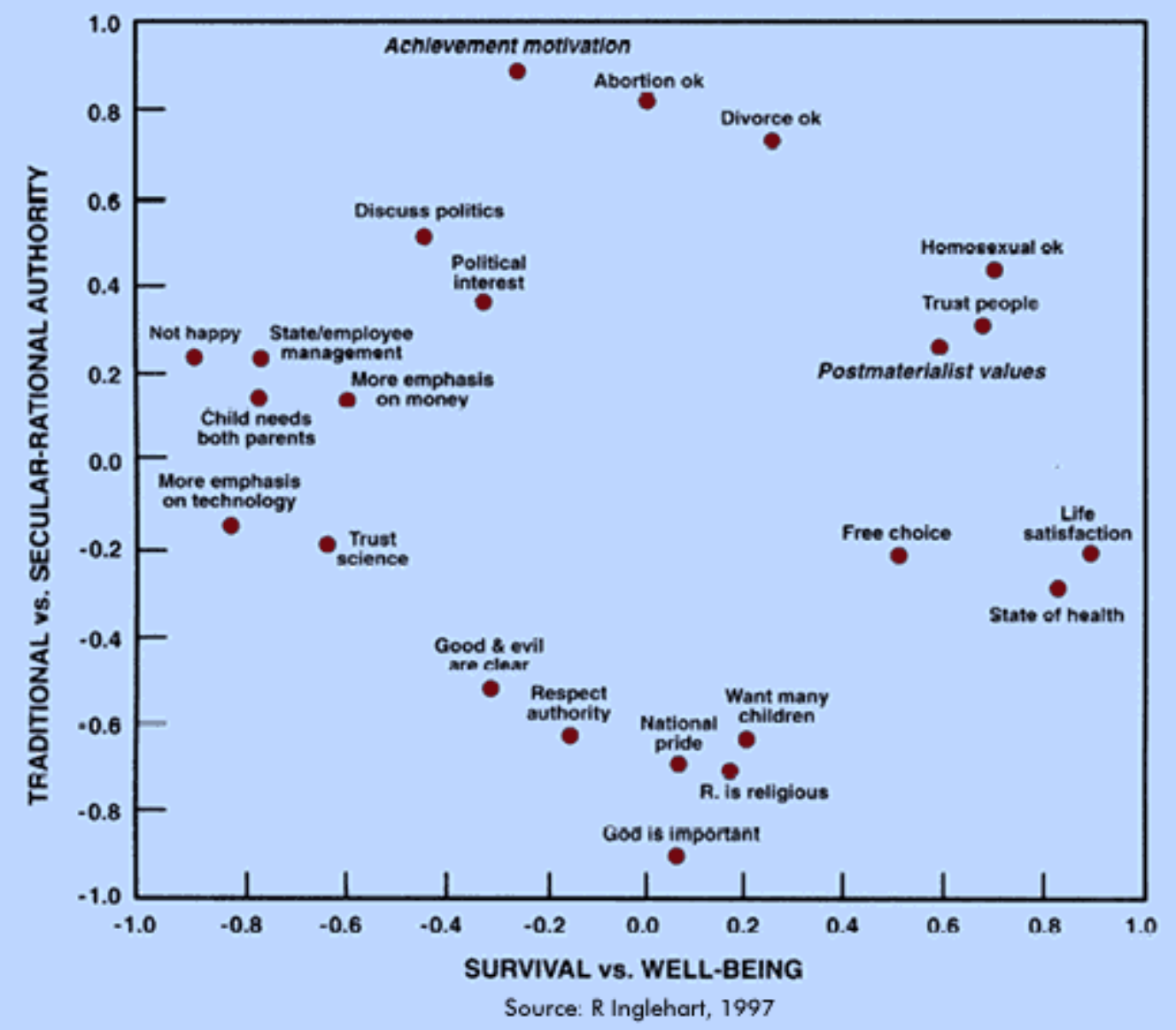

Fig. 2 : Typical attitudes which correspond to different positions on the cultural world-map (Source: http://wvs.isr.umich.edu/index.html) 
That the development in both dimensions is correlated with economic progress and prosperity is shown in the fig. 3 .

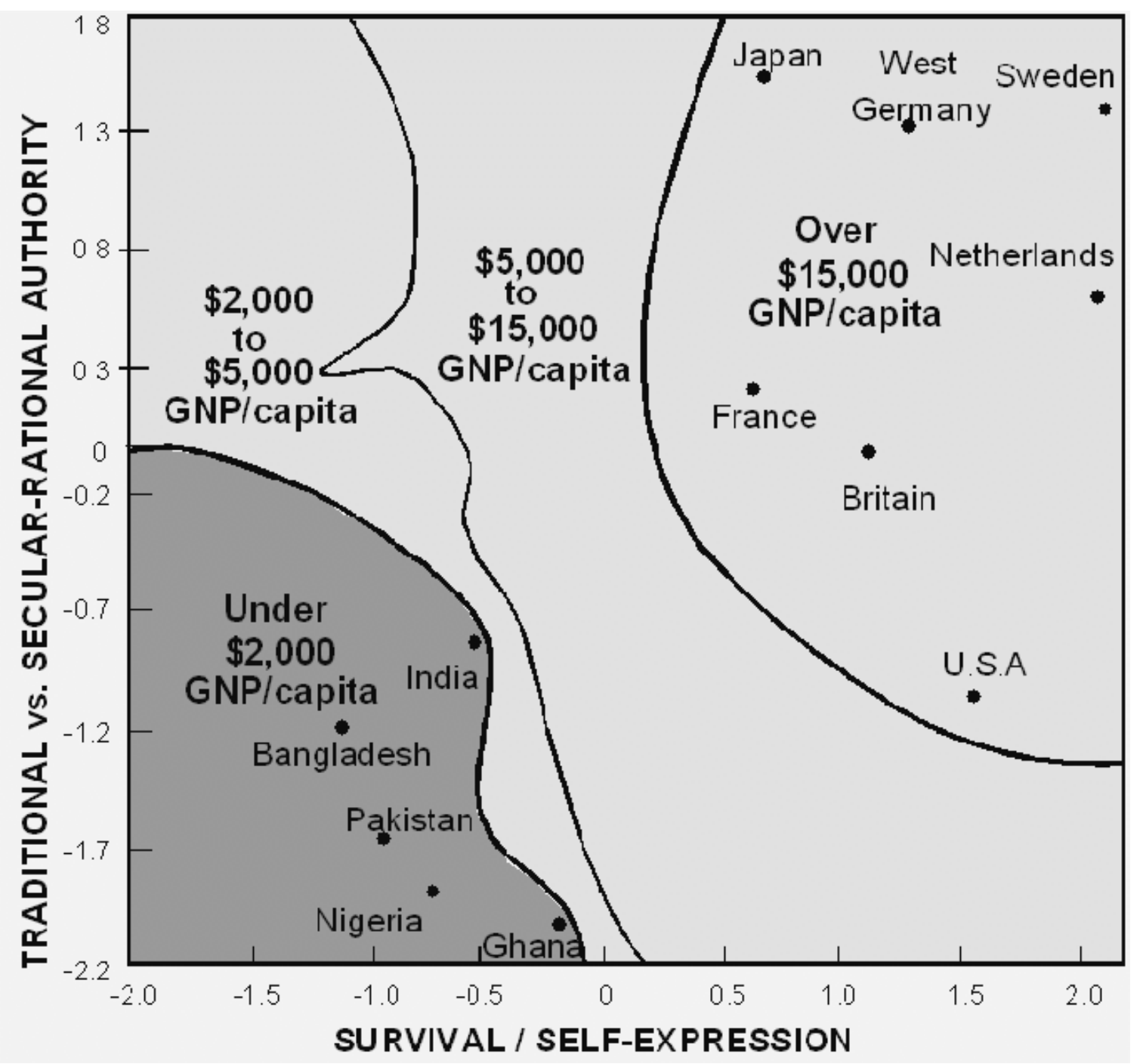

Fig. 3 Correlation of the two factors with economic progress. GNP/capita $=$ gross national product per head). Findings from 1995. The fig. is based on all nations; only some are drawn into it. (Source: http://wvs.isr.umich.edu/index.html.)

As a defender of modernization theory, Inglehart believes that modernization goes hand in hand with economic progress, progress in freedom and democracy, and increase of happiness and self-satisfaction of people. Not all of these claims are supported by the WVS-data:

$\Rightarrow$ Correlation with economic progress is clearly supported, as shown in fig. 3.

$\Rightarrow$ Correlation between post-modernization (importance of self-realization) and democratic development as measured by the so-called Freedom House 
index is also supported (cf. the figure in Inglehart 2004, 161, and the WVS homepage).

$\Rightarrow$ What remains doubtful, or is only weakly supported, is the correlation between self-satisfaction and modernization. Since modernization correlates with GNP per capita, this can be seen from the figure 4 (findings from 1995).

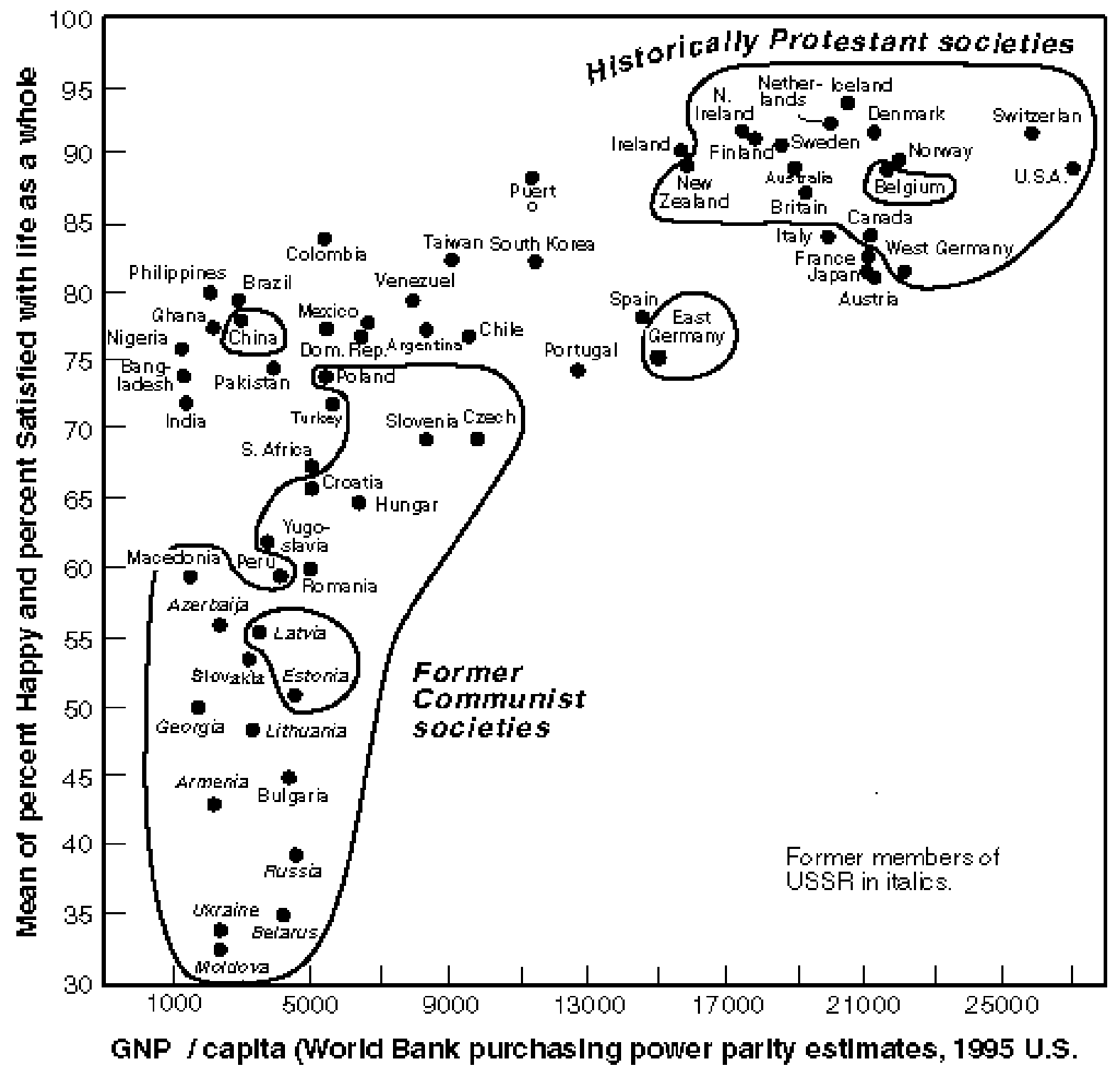

Fig. 4: Correlation of happiness/self-satisfaction with GNP per capita. (Source: http://wvs.isr.umich.edu/index.html.).

On peculiar historical reasons, the ex-communist countries have a special position which gives the false impression of a high correlation. If they are omitted from the figure, the correlation is low: people in Ghana, China, or Mexico are not less happy than those in Austria, France or West Germany, 
although their economic position is almost on the opposite end. On the other hand, differences between rich countries, such as France or Netherlands, are rather high.

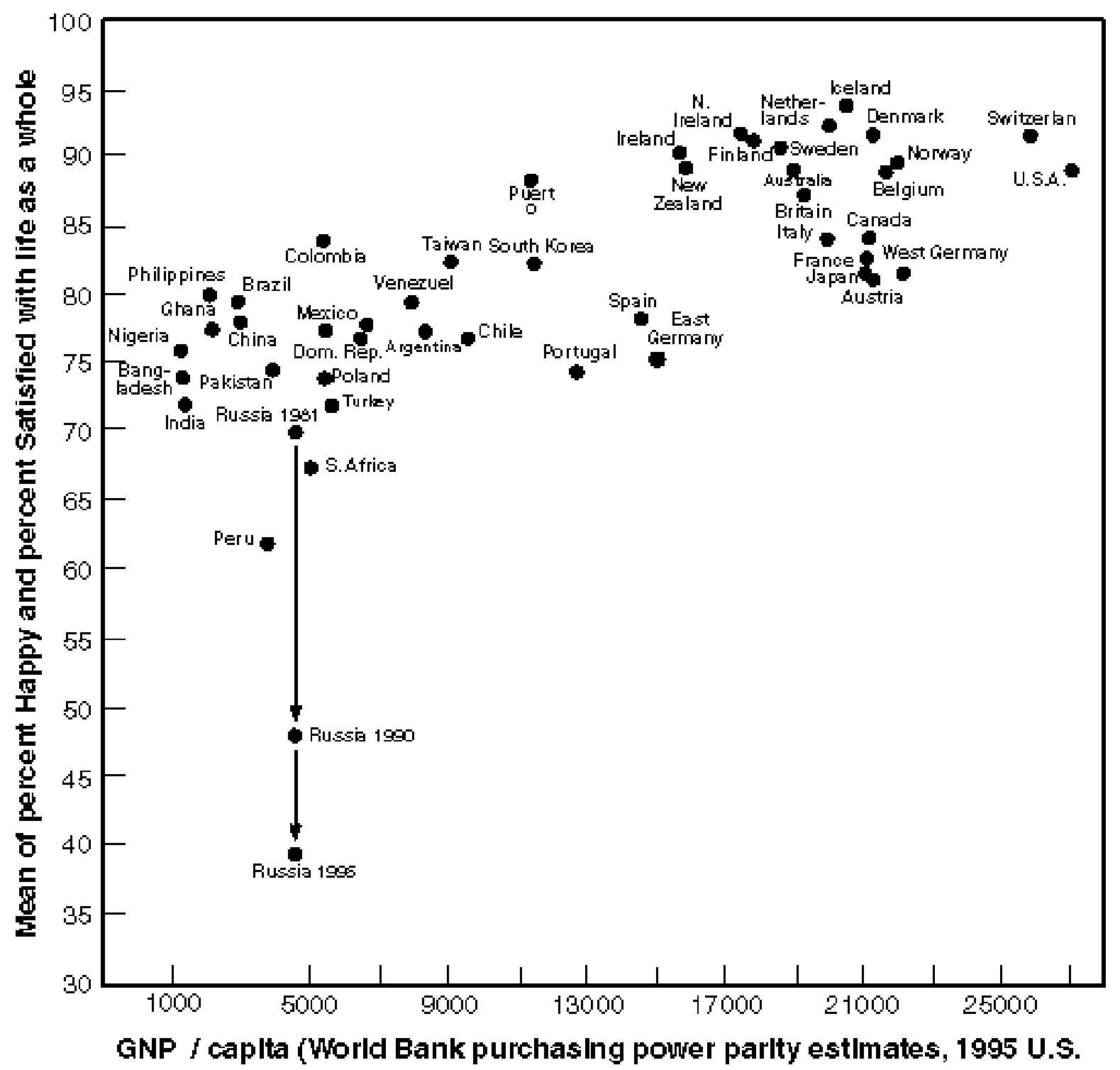

Fig. 5: Dissatisfaction in ex-communist countries - at hand of Russia. (Source: http://wvs.isr.umich.edu/index.html.)

The dissatisfaction of the people in the ex-communistic countries is caused by the fact that these people had very high expectations towards the new 'free' society which was promised to them after the breakdown of communism, and their expectations had been strongly disappointed. This is show in figure 5 at hand of data from Russia during 15 years: the percentage of people who say that they are satisfied with their life has fallen down from $70 \%$ in the year 1981 to only $48 \%$ in 1990 and $38 \%$ in 1996. 


\section{Empirical Data on Evolutionary Trends}

Developmental data are available only concerning the last decades. Figure 6 shows the change of cultural positions of 39 countries in the years from 1981 or 1990 to 1997 (time intervals are different because not all countries have been investigated in earlier questionnaires). It can be seen that the rate of cultural changes as well as their directions are rather diverse:

$\Rightarrow$ From 39 countries only 13 have followed the direction of modernization, i.e. have developed forward along both axes - where "forward" has to put in quotation marks.

$\Rightarrow 6$ countries (Russia, Belarus, Great Britain, Estonia, South Africa and Nigeria) have developed backwards along both axes.

$\Rightarrow 12$ countries have developed backwards to the traditional side, along the axes traditional vs. rational (South Africa, Brazil, Argentine, Turkey, India, Ireland and North Ireland; and in minor way also Spain, Italy, France, USA, South Korea).

$\Rightarrow 7$ countries, most of them ex-communist countries, have developed backwards to the survival side, along the axis survival versus selfexpression.

$\Rightarrow$ The most rapid cultural change has taken place in Poland, EastGermany and other ex-communist countries; but also Western Germany, Netherlands or Sweden a fast cultural change has taken place.

In conclusion: modernization theory is hardly supported on the short term scale. One may object that modernization is a long term development and cannot be judged at the level of decades - short time reversals are compatible with long term modernization trend. So let us finally ask:

Are modernization and post-modernization really stable universal long-term trends?

$\Rightarrow$ Concerning post-modernization: So far, this is not the case. The shift towards post-modern values is a very young phenomenon which has taken place in the Western generations after the second world war. This is shown by figure 7 . and is supported by similar diagrams (cf. Norris/Inglehart 2004) which I omit here. Insofar post-modernization is characterized by a retreat of traditional family values, by low birth rates, and an increase 


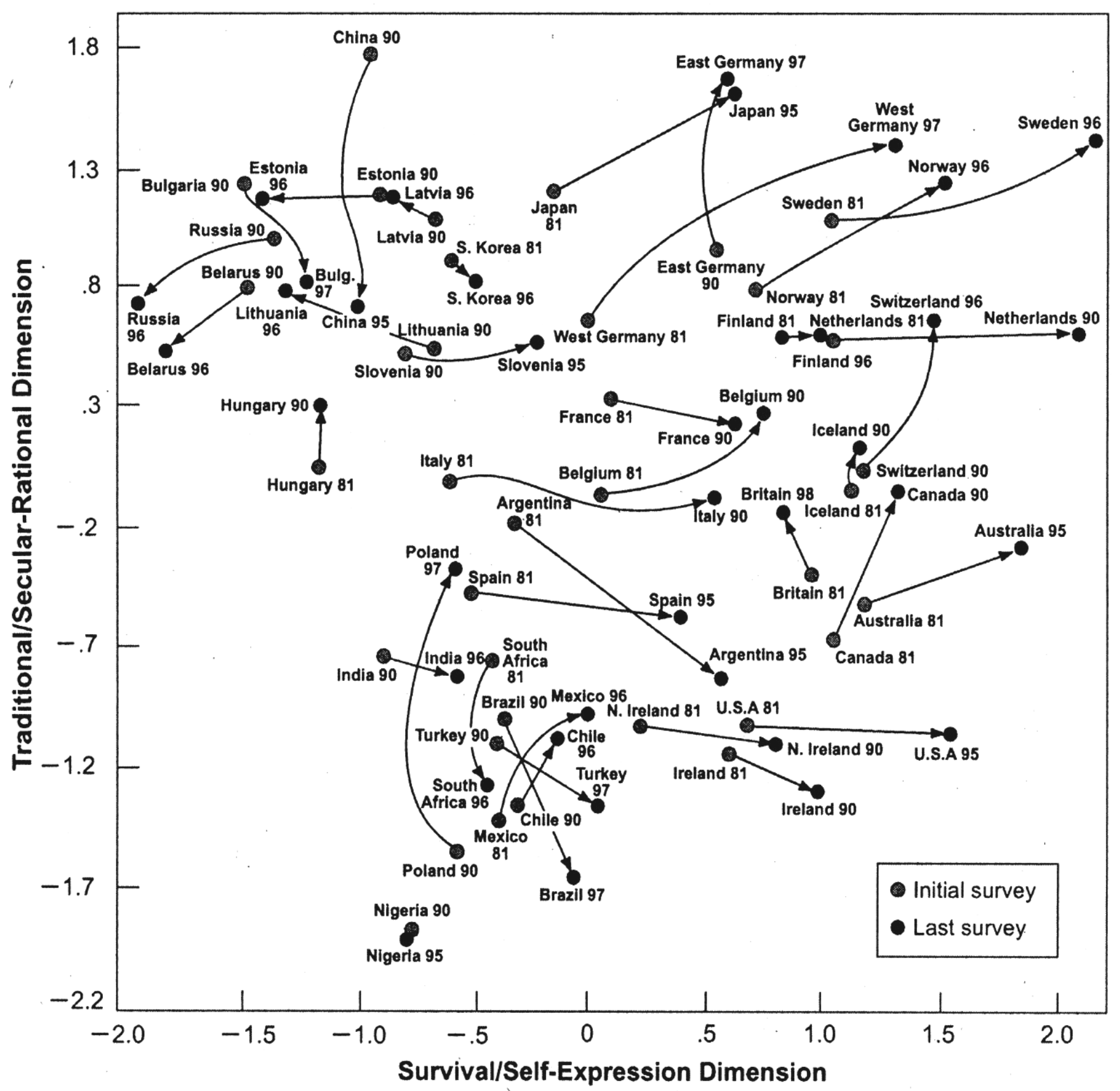

Fig. 6 Change of cultural positions of 39 countries in the last decade(s). (Source: Inglehart/Baker 2004, 161. See also http://wvs.isr.umich.edu/index.html)

of single life style, it is doubtful whether this can really be an enduringly stable cultural equilibrium - in particular, since this life-style depends on high economic prosperity which can hardly be sustained, because of ecological problems as well as on demographic reasons. Moreover, the high prosperity on which post-modern values depend can hardly be realized for the majority of humans living on earth. 


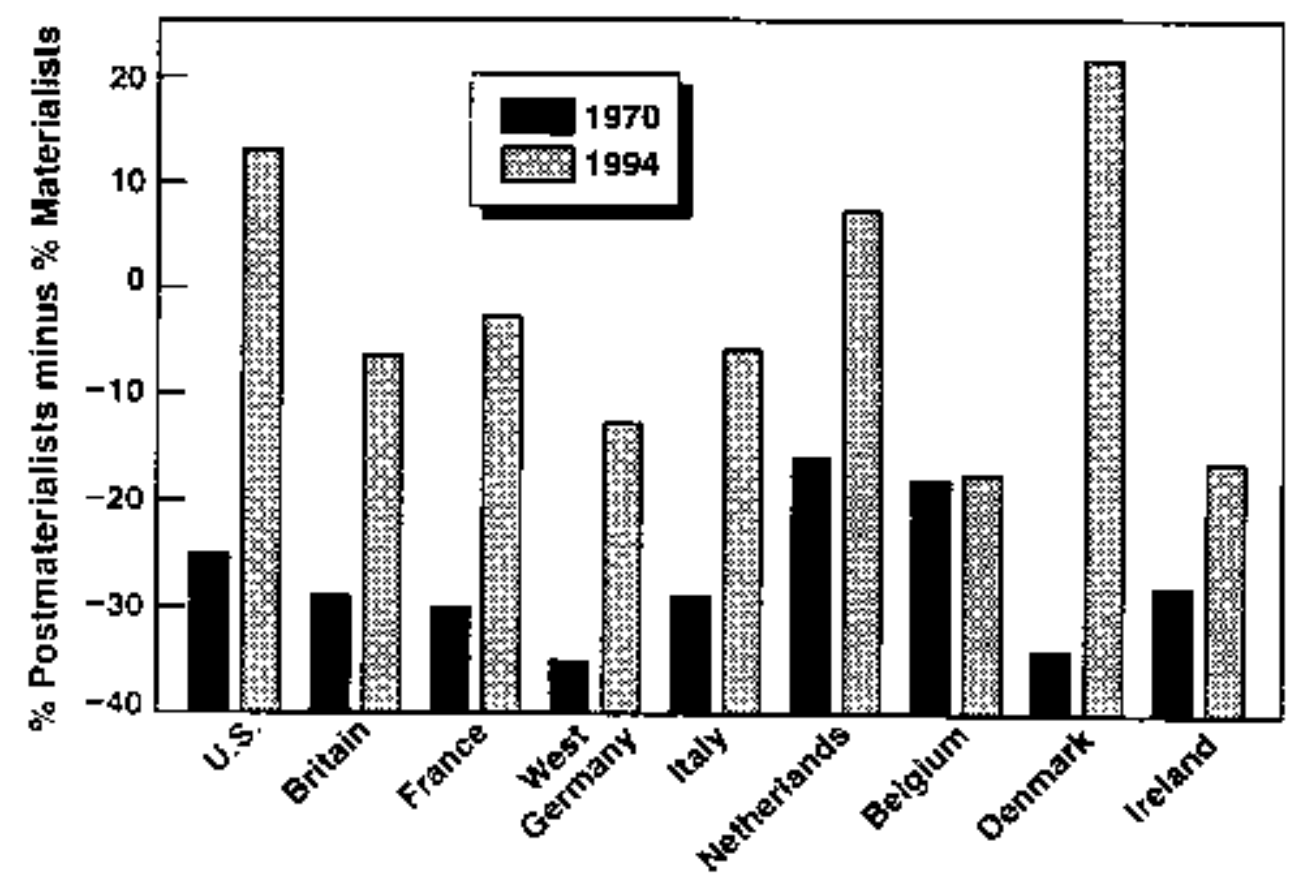

Fig. 7: The transition towards dominantly post-modern attitudes is a very young phenomenon (Source: http://wvs.isr.umich.edu/index.html.)

$\Rightarrow$ Concerning modernization: Rationalization, increase of education, secularization, democratization, realization of equal human rights seem to be long term developments, which have taken place in the Western countries for several centuries. But even here things are not so simple: while religious activities have declined during this development, religiosity as such has dropped down a little, and has recovered during postmodernization. Figure 8 shows that while the attendance of religious activities has declined in post-industrial societies, identification as religious and belief in life after death have increased a little bit.

$\%$ Believe in God

$\%$ Believe in life after death

$\%$ Religion 'very important'

$\%$ Identify as religious

$\%$ Comfort from religion

$\%$ Attend religious service regularly

Mean religiosity 100-point scale
Agrarian Industrial Postindustrial Total

$\begin{array}{llll}91 & 80 & 79 & 83\end{array}$

$\begin{array}{llll}83 & 62 & 68 & 69\end{array}$

$\begin{array}{llll}87 & 60 & 55 & 64\end{array}$

$\begin{array}{llll}73 & 58 & 59 & 61\end{array}$

$\begin{array}{llll}74 & 51 & 46 & 54\end{array}$

47

73 45 21 28

Fig. 8: Importance of religion in agrarian, industrial and postindustrial societies. (After Inglehart/Norris 2003b, 55; table 3.2.)

So it seems that, at least to some degree, humans have a desire towards 
religious orientations independent of the degree of modernization. This is further supported by figure 9, which shows that the correlation between religiosity (as measured by several indices) and modernization is little, and that between religiosity and post-modernization is almost zero.

In conclusion, the data show that religion is compatible with modernized democratic societies - but of course, only in its secularized form, in which the religious authorities are separated from the state authority. In this respect, Islamic countries are clearly in a pre-modern stage.

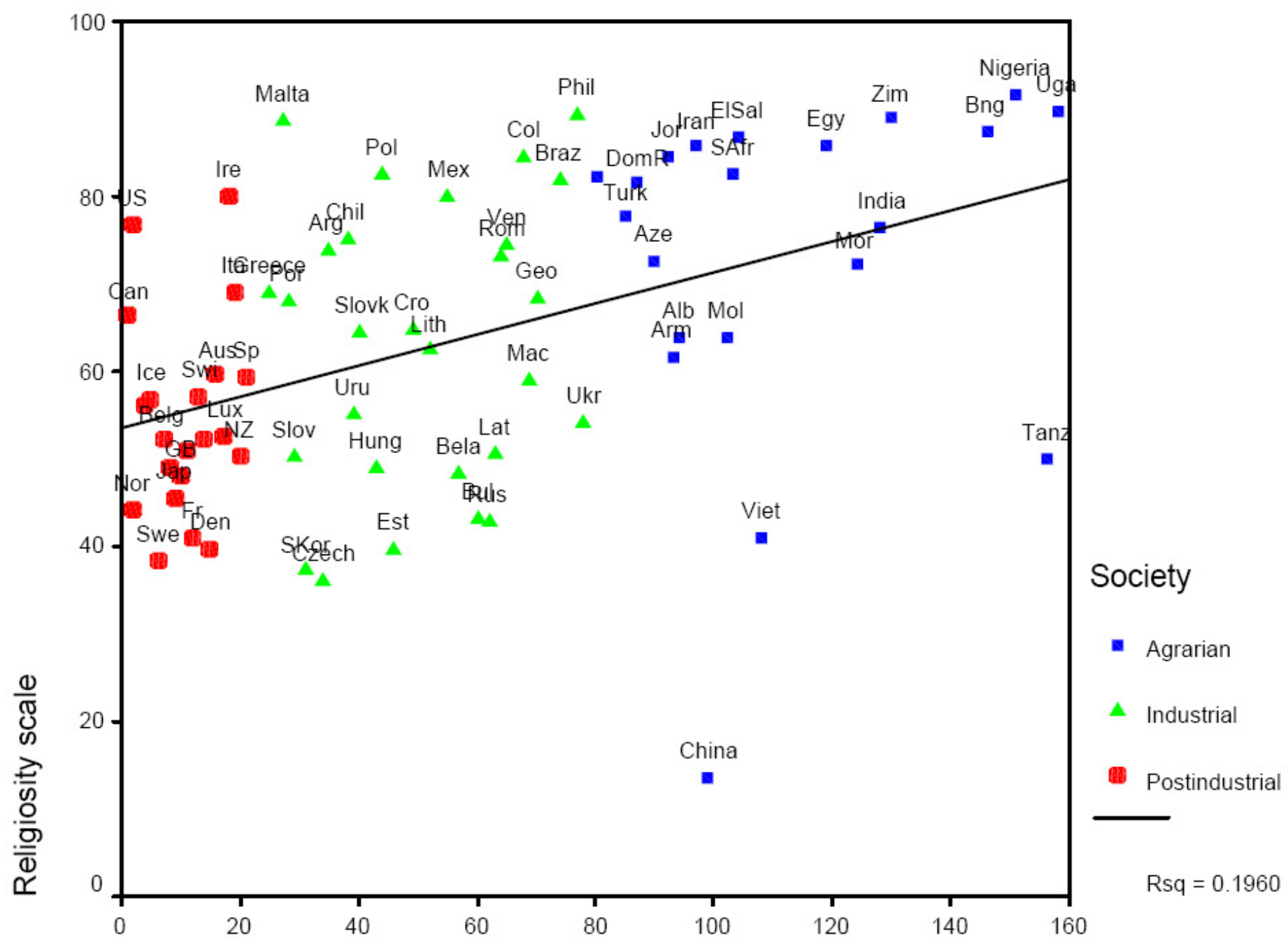

Human development (HDI Rank, 1998 High to Low)

Fig. 9: Religiosity (multiple indices) in agrarian, industrial, and post-industrial nations (Source: Inglehart/Norris 2003b, http://www.pippanorris.com, draft version, ch. 3, fig. 3.2).

Although religion and many specific history-dependent cultural values and 
habits may survive in modernization, one may still ask:

Are at least secularization, progress to democracy and to equal human rights three major trends which must go hand in hand with economic \& technical progress?

Interesting in this respect is a recent investigation of Inglehart and Pippa Norris: their data show that the true cultural clash between Western and Islamic cultures does not lie (so much) in their attitude towards democracy vs. state authority, but in their values concerning family life and gender roles (in combination with religious attitudes). Inglehart and Norris (2003a, 2003b) have compared 11 Islamic countries (Albania, Algeria, Azerbaijan, Bangladesh, Egypt, Indonesia, Iran, Jordan, Marocco, Pakistan, and Turkey) with 22 Western Countries (9 West-European, USA, Australia, New Zealand, and 10 ex-communist countries):

\begin{tabular}{|lcc|}
\hline \multicolumn{1}{|c}{$(\%-$ Agreement) } & Western countries & Islamic countries \\
Democracy performs well & $68 \%$ & $68 \%$ \\
In favor of democracy & $86 \%$ & $87 \%$ \\
Rejection of authoritarian political leaders & $61 \%$ & $61 \%$ \\
Rejection of religious political leaders & $62 \%$ & $39 \%$ \\
Gender equality is good & $82 \%$ & $55 \%$ \\
Divorce should be admitted & $60 \%$ & $35 \%$ \\
Abortion should be admitted & $48 \%$ & $25 \%$ \\
Homosexuality should be admitted & $53 \%$ & $12 \%$ \\
\hline
\end{tabular}

Fig. 10: Difference in attitudes between 11 Islamic vs. 22 Western countries (9 excommunist. Based on WVS-questionnaires 1995-6 and 2002-2. After Inglehart/Norris (2003a, 69f).

So also the people in the Islamic countries want democracy. But do they really mean the same with this word as Western societies? Their values concerning religious authority and in particular concerning the individual freedom in one's choice of life-style seem to be in conflict with a democratic constitution. For me this data indicate that although people in these countries want democracy - in a vague sense as a system 'ruled by the people' - but in several respects they do not seem to be mature for democracy. So I am inclined to draw the following conclusion: instead of attempting a forceful establishment of democracy onto countries whose people have pre-modern values concerning life-style and freedom of choice, the western countries have to wait until people in these countries are mature for democracy and are able develop it on their own feet. In the mean- 
time, the most important task is the sustainment of a peaceful co-existence of the different world-cultures - which does not exclude to foster democratic developments in these countries by peaceful means such as economic or educational support, etc.

As a general conclusion of this paper I suggest the following one: altogether it seems that cultural evolution does not follow a uniform trend, but stands under opposite evolutionary forces or selection factors, whose strength are mainly dependent on the level of economy and education. The location of cultural equilibria in the cultural world-map - the regions in which societies stay stable for long time - are largely dependent on the constellation and the mutual balance of these forces. The following schema presents a simplified sketch of this view:

TRADITIONAL VALUES

General selection factors:

Pressure of Survival

Biological Heritage

Special selection factors:

Poverty

Low Education

High birth rate

Traditional Gender Roles

High Criminality

Existential Threat

Monocracy
Modern VALUes

General selection factors:

Pressure of Modernization

Economic-Technical Progress

EVOLUTIONARY FORCES

Special selection factors:

Prosperity

High Education

Low birth rate

Equalizing Gender Roles

Low Criminality

Existential Security

Democracy

\section{REFERENCES}

Huntington, S. P. 1996 Kampf der Kulturen, München: Goldmann (engl. 1996: The Clash of Civilizations"; quotations refer to the German edition).

Inglehart, R. 1998 Modernisierung und Postmodernisierung, Frankfurt/M.: Campus (engl. 1997).

- 2004 "Kultur und Demokratie", in S. P. Huntington and L. E. Harrison (eds.), Streit um Werte, München: Goldmann, 141-166. nglehart, R. 2004 "Kultur und Demokratie", in S. P. Huntington and L. E. Harrison (eds.), Streit um Werte, München: Goldmann, 141-166. 
Inglehart, R., and Baker, W. 2000 Modernization, Cultural Change, and the Persistence of Traditional Values", American Sociological Review, 65, 19-51.

Inglehart, R., and Norris, P. 2003a "The True Clash of Civilizations", Foreign Policy March/April 2003, 67-74.

- 2003b Rising Tide: Gender Equality and Cultural Change Around the World, Cambridge/MA: Cambridge University Press.

- 2004 Sacred and Secular. Religion and Politics Worldwide, New York: Cambridge Univ. Press.

Kienzler, K. (1996) Der religiöse Fundamentalismus, C.H. Beck, München.

Metzinger, U. 2000 Die Huntington-Debatte, Köln: SH-Verlag.

Müller, H. 1998 Das Zusammenleben der Kulturen. Ein Gegenentwurf zu Huntington, Frankfurt/M.: Fischer.

Riesebrodt, M. 2000 Die Rückkehr der Religionen, München: C.H. Beck-Verlag. 